\title{
Porovnání úrovně motorických schopností romských a neromských žáků
}

\section{Comparation of mobility skills of pupils of Romany and Non-Romany ethnicity}

\author{
Ondřej Ješina, Michaela Matochová, Klára Růžičková
}

Fakulta tělesné kultury Univerzity Palackého v Olomouci, Česká republika

\begin{abstract}
Abstrakt
Tělocvičné aktivity představují činnosti, při kterých člověk více či méně svobodně participuje, projevuje se, uči a ověruje si své dosavadní vědomosti, dovednosti a schopnosti. Vzhledem k zaměření šetřrení jsou důležitá především specifika v úrovni pohybových schopností u žáků romského etika. Cílem šetření je analýza, deskripce a komparace úrovně vybraných motorických schopností žáků romského etnika ve věku 9-13 let a jejich vrstevníkù většinové populace. K testování úrovně motorických schopností jsme využili kombinací dvou standardizovaných testových baterií EUROFIT a UNIFIT (Měkota \& Kovár, 1996). Výzkumného šetření se zúčastnilo celkem 263 probandů ze základních škol z Přerova, Břeclavi, Vsetína a Ostravy. 118 $z$ nich je možné zařadit mezi žáky romského etnika, $z$ nich bylo 90 chlapců a 28 dívek. Neromských žáků se zúčastnilo 145. Z tohoto vzorku je 99 chlapců a 46 dívek. Neromští chlapci dosáhli vyšši výsledky než chlapci romského etnika predevším $v$ předklonu. U divek jsme zaznamenali lepší výsledek u neromských dívek ve výdrži, ve shybu a ve skoku z místa. Romské dívky dosáhly lepšího výsledku než neromské dívky předevšim $v$ člunkovém běhu. Žádná diference ve zjištěných parametrech však nebyla statisticky významná na hladině významnosti $p<0,05$.
\end{abstract}

\section{Abstract}

Physical activity represents such actions, in which people more or less freely participate, express themselves, learn and verify their knowledge, skills and ideas. The aim is to analyse and describe mobility skills selected pupils of Romany ethnicity at age 9-13 years. We utilize a combination of two standardised test battery EUROFIT and UNIFIT (Měkota \& Kovár, 1996) to test other capabilities. Research investigation involving a total of 263 obtained from basic schools from Přrerov, Břeclav, Vsetín and Ostrava. 118 of them can be classified among the pupils of Romany ethnicity, of which 28 were boys and 90 girls. The pupils attended the 145-Nonromanies. This sample is 99 boys and 46 girls..

Especially in the front band, the results of non-Romany boys are qualitatively at the better level than for boys of Romany ethnicity. For girls were find differences already pronounced. Clearly we have had a better result for non-Romany girls in pull-up stamina and standing long jump. Romany girls achieved a better result than non-Romany girls especially in runtime. No differences in the established parameters, however, was not statistically significant on the level $p<0,05$.

Klíčová slova: $\quad$ pohybové schopnosti, žáci 9-13 let, romské etnikum

Key words: $\quad$ mobility skills, pupils at age 9-13 year, Romany ethnicity

Př́spěvek je součástí projektu Centra podpory integrace CZ 1.07/1.2.00/08.0117 podporovaného ESF a rozpočtem $\check{C} R$.

\section{Úvod}

Pravidelná tělesná cvičení jsou vhodným prostředkem pro celkové zdraví a zlepšení kvality života jedinců všech věkových skupin (Freedson, 1991; Trost, Pate, Saunders et al., 1997). Tělesné cvičení (jako prostředek zabezpečující tělesnou kulturu dle Hodaně) je do značné míry také predikátorem míry zdraví dětí a mládeže (Sallis \& Patrick, 1994; Baranowski, Bouchard, Bar-Or et al., 1994). Jelikož se ve své studii zabývá problematikou žáků romského etnika ve věku 9 - 13 let, snažili jsme se zjistit výsledky šetře- 
ní uskutečněných v zahraničí, které se zabývaly právě touto věkovou skupinou a její pohybovou aktivitou či inaktivitou. Zaměřili jsme se právě na ty výzkumy, které uvažovaly o vztazích subsystémů tělesné kultury a jedinců z různých etnických skupin či se sociálním znevýhodněním. Zajímavé studie byly uskutečněny organizací Centers for Disease Control and Prevention v USA (2004). Na základě výsledků těchto studií došli odborníci $\mathrm{k}$ zjištění, že pohybovou inaktivitou trpí více než třetina zkoumaných jedinců na druhých stupních základních škol (dle systému v ČR). Sallis, Prochaska a Taylor (2000) pak uvádí, že jednou z nejvýznamnějších determinant pohybové aktivity či inaktivity u dětí a mládeže této věkové skupiny je etnický původ. Tato zjištění potvrdila již dřive provedená šetření (Sallis, Patterson, Buono et al., 1988). Přesto se objevují i ojedinělá šetření, která vliv etnické příslušnosti nepotvrzují (Pate, Trost, Felton et al., 1997).

Vzhledem k zaměření práce jsou důležitá především specifika v motorické kompetenci u žáků romského etika. Trochtová (2002) uvádí, že díky dostatku přirozeného pohybu je hrubá motorika u těchto žáků přiměřené vyvinutá, avšak vývoj jemné motoriky je velmi nízký. Stejná autorka pak přirovnává úroveň motoriky šestiletého romského dítěte k úrovni tř́letého neromského dítěte. S tím souvisí i některé školní dovednosti ve spojení s grafomotorikou. Belásová (2001) upozorňuje na to, že po absolvování první třídy základní školy není grafomotorická úroveň u romských žáků dostačující. Někteří další autoři (Šotkovská \& Hugec, 1999; Turek \& Hugec, 1996) upozorňují, že všeobecná pohybová výkonnost romských žáků je na nižší úrovni, než je tomu u jejich neromských vrstevníků. Zmiňují především nedostatečnost v pohybových aktivitách vytrvalostního charakteru a celkovou nerovnoměrnou akceleraci předpokládaného motorického vývoje. Apelují na vliv tělesné výchovy jako možnosti pozitivního působení především vytrvalostních schopností a s tím související využití různých motivačních prostředků. Z hlediska preferencí potvrzuje Liba (1999) zájem u romských dětí o pohybové a sportovní hry a cvičení s hudbou.

Tělocvičné aktivity představují činnosti, při kterých člověk více či méně svobodně participuje, projevuje se, učí a ověřuje si své dosavadní vědomosti, dovednosti a představy. Nabízí nám možnost pracovat $s$ jedincem $v$ relativně přirozeném prostředí, ve němž se většinou projevuje bez sociálních masek, a tím se vytváří prostor pro diagnostiku a pozitivní ovlivnění osobnosti či hodnot. V rámci strategie a realizace multikulturního vzdělávání je považováno zařazení tělocvičných aktivit za nezbytné (Boyce, 1996; Butt \& Pahnos, 1995; Harrison \& Worthy, 2001; Hodge, 1997; Hutchinson, 1995; Chepyator-Thomson, 1994; Kahan, 2003; King, 1994; McCollum, Civlier, \& Holt, 2004; Sparks, 1994; Sutherland \& Hodge, 2001; Sutliff, 1996; Sutliff \& Perry, 2000; Wessinger, 1994). Block (2007) však upozorňuje na nedostatek výzkumů $\mathrm{v}$ rámci multikulturního vzdělávání, neexistenci zdrojů zaměřených na tuto problematiku a jinakost ve spojení s aplikovanými pohybovými aktivitami. Studie a články týkající se multikulturního vzdělávání a tělocvičných aktivit se zaměřují hlavně na seznamovací hry, tance různých zemí a kultur v kurikulu tělesné výchovy (Block, 2007).

\section{Výzkumný záměr}

Předkládaný př́spěvek je orientován na specifika rozvoje motorických schopností žáků romského etnika v České republice. Cílem předkládané práce je analýza a deskripce vybraných motorických schopností žáků romského etnika ve věku 9-13 let.

\section{Výzkumné otázky}

1. Jaká je úroveň motorických schopností chlapců a dívek romského etnika v komparaci s neromskými spolužáky?

2. Jak se vyvíjí úroveň motorických schopností u žáků romského etnika v průběhu základního vzdělávání (9-13 let)?

\section{Metodika}

Z hlediska technik sběru dat jsme využili testování motorických schopností. Kombinací dvou standardizovaných testových baterií EUROFIT a UNIFIT (Měkota \& Kovář, 1996) jsme po konzultaci s odbor- 
níky Centra kinantropologického výzkumu FTK UP v Olomouci vytvořili testový systém skládající se ze 4 samostatných testů vhodných pro obě pohlaví žáků druhého stupně ZŠ:

- test explozivní síly - skok daleký z místa,

- test pohyblivosti - hluboký ohnutý předklon,

- test silových schopností,

- chlapci - shyby na hrazdè,

- dívky - výdrž ve shybu na hrazdě,

- test rychlosti - člunkový běh.

Po hromadném jednotně vedeném rozcvičení jsme probandy rozdělili do skupin. Skupiny probandů postupně absolvovaly jednotlivá testovací stanoviště. Člunkový běh jsme zařadili až na konec celého testování, a to $\mathrm{z}$ důvodu bezpečnosti, dostatku prostoru pro samotný test a s ohledem na specifika fyzického zatížení. Se zřetelem na fyzické nároky testů bylo probandům doporučeno nejíst 2 hodiny před testováním a neprovádět fyzicky náročné činnosti.

\section{Charakteristika zkoumaného souboru}

Výzkumný soubor je tvořen probandy romského etnika ve věku 9 až 13 let navštěvujícími základní školy v České republice. Osloveny byly především školy s převažujícími žáky romského etnika pobývajícími v sociálně vyloučených oblastech, které v současné době díky mnoha aktuálním transformacím aplikují RVP-ZV - s př́lohou pro žáky s lehkým mentálním postižením. Dále jsme oslovili komunitní centra pracující především v sociálně vyloučených oblastech, které byla $\mathrm{v}$ době šetření přesně popsána a definována v rámci geograficko-sociálních údajů Ministerstva práce a sociálních věcí a Ministerstva pro lidská práva. $V$ prŕpadě výsledků testů motorických dovedností jsme komparovali probandy romského etnika a jejich neromské vrstevníky.

Výzkum proběhl formou výběrového šetření, tedy sledování skupiny jedinců bez záměrného ovlivňování (Hendl, 2004). Při oslovování výzkumného souboru jsme použili formu náhrady prostého náhodného výběru, a to konkrétně vícestupňového shlukového výběru. Vybrali jsme náhodný vzorek krajů a v nich nahodilý vzorek komunitních a školských zařízení. V rámci těch jsme pak provedli náhodný výběr a aplikovali postupy určené pro zpracování dat $\mathrm{z}$ prostých náhodných výběrů.

Výzkumného šetření se zúčastnilo celkem 263 probandů ze základních škol z Přerova, Břeclavi, Vsetína a Ostravy. 118 z nich je možné zařadit mezi žáky romského etnika, z nich bylo 90 chlapců a 28 dívek. Průměrný věk je 11,2 let (chlapci 11,3 let a dívky 10,9 let). Neromských žáků se zúčastnilo 145 . Z tohoto vzorku je 99 chlapců a 46 dívek. Jejich průměrný věk je 11,6 let (chlapci 11,7 let a dívky 11,4 let). Celkem je průměrný věk probandů 11,4 let (chlapci 11,5 let a dívky 11,2 let).

\begin{tabular}{|c|c|c|c|c|c|}
\cline { 2 - 6 } \multicolumn{1}{c|}{} & Romští chlapci & Romské dívky & Neromští chlapci & Neromské dívky & Celkem \\
\hline 9 let & 17 žáků & 7 žáků & 9 žáků & 6 žáků & 39 \\
\hline 10 let & 9 & 5 & 10 & 6 & 30 \\
\hline 11 let & 20 & 5 & 17 & 10 & 52 \\
\hline 12 let & 15 & 5 & 33 & 12 & 65 \\
\hline 13 let & 29 & 6 & 30 & 12 & 77 \\
\hline Celkem & 90 & 28 & 99 & 46 & 263 \\
\hline
\end{tabular}

Tabulka 1 Věkové rozložení zkoumané skupiny

\section{Statistické a matematické zpracování dat}

Matematických metod bylo využito při výpočtu aritmetického průměru při vypočítávání výsledných průměrných hodnot výkonů žáků u výsledkủ testové baterie. Při vyhodnocování dat jsme využili základ- 
ních statistických postupů pro basální deskripci dosažených dat - minimum, maximum, medián, směrodatnou odchylku v programu Microsoft Excel 2007. S pomocí statistického programu Statistika 7 jsme využili t-test (chlapci) a Mann-Whitneyův test (děvčata) pro zjištění statistické významnosti vybraných vztahů.

\section{Výsledky a diskuse}

Výsledky testů uvádíme přehledně v tabulkách a grafech. Z výsledků je patrné, že neromští žáci dosahují ve většině testů vyšších výsledků. Především v předklonu jsou výsledky u neromských chlapců $(0.17 \mathrm{~cm})$ na kvalitativně lepší úrovni než u chlapců romského etnika $(-1.53 \mathrm{~cm})$. U dívek byly rozdíly již výraznější. Zřetelně lepší výsledek jsme zaznamenali u neromských dívek ve výdrži ve shybu (6.63 s) a ve skoku z místa $(145.3 \mathrm{~cm})$. Romské dívky dosáhly lepšího výsledku než neromské dívky především v běhu (13.29 s).

Tabulka 2 Popisné statistiky všech chlapců zkoumaného souboru

\begin{tabular}{|c|c|c|c|c|}
\hline $\begin{array}{c}\text { Test } \\
\mathrm{N}=189\end{array}$ & Průměr & Minimum & Maximum & Sm. odch. \\
\hline běh & 10.89 & 9.12 & 15.32 & 1.12531 \\
\hline shyby & 2.49 & 0 & 15 & 2.85018 \\
\hline předklon & -0.37 & -30 & 16 & 9.33024 \\
\hline skok & 181.68 & 130 & 263 & 27.6364 \\
\hline
\end{tabular}

Tabulka 3 Popisné statistiky chlapců romského etnika

\begin{tabular}{|c|c|c|c|c|}
\hline $\begin{array}{c}\text { Test } \\
\text { N=90 }\end{array}$ & Průměr & Minimum & Maximum & Sm.odch. \\
\hline běh & 10.69 & 9.25 & 15.32 & 1.23018 \\
\hline shyby & 2.33 & 0 & 9 & 2.61736 \\
\hline předklon & -1.53 & -17 & 15 & 9.67305 \\
\hline skok & 183.50 & 140 & 263 & 26.5548 \\
\hline
\end{tabular}

Tabulka 4 Popisné statistiky chlapců neromských

\begin{tabular}{|c|c|c|c|c|}
\hline $\begin{array}{c}\text { Test } \\
\text { N=99 }\end{array}$ & Průměr & Minimum & Maximum & Sm. odch. \\
\hline běh & 10.98 & 9.12 & 14.27 & 1.07 \\
\hline shyby & 2.56 & 0 & 15 & 2.97009 \\
\hline předklon & 0.17 & -30 & 16 & 9.19205 \\
\hline skok & 180.83 & 130 & 260 & 28.2941 \\
\hline
\end{tabular}


Tabulka 5 Výsledné hodnoty zpracované podle t-testu

\begin{tabular}{|c|c|c|c|c|c|c|c|c|}
\hline \multicolumn{8}{|c|}{ t-test N=189 } \\
\hline & $\mathrm{t}$ & $\mathrm{p}$ & $\begin{array}{c}\text { Poč.plat } \\
\text { Neromů }\end{array}$ & $\begin{array}{c}\text { Poč.plat. } \\
\text { Romů }\end{array}$ & $\begin{array}{c}\text { Sm.odch. } \\
\text { Neromů }\end{array}$ & $\begin{array}{c}\text { Sm.odch. } \\
\text { Romů }\end{array}$ & $\begin{array}{c}\text { F-poměr } \\
\text { rozptyly }\end{array}$ & $\begin{array}{c}\mathrm{p} \\
\text { rozptyly }\end{array}$ \\
\hline běh & 1.178533 & 0.241624 & 99 & 90 & 1.07 & 1.23018 & 1.321817 & 0.353788 \\
\hline shyby & 0.361682 & 0.718419 & 99 & 90 & 2.97009 & 2.61736 & 1.287692 & 0.459336 \\
\hline předklon & 0.82456 & 0.411754 & 99 & 90 & 9.19205 & 9.67305 & 1.107393 & 0.718279 \\
\hline skok & -0.43503 & 0.664558 & 99 & 90 & 28.29412 & 26.55476 & 1.135292 & 0.722508 \\
\hline
\end{tabular}

Z hlediska diference u chlapců potvrzujeme některé předešlé výzkumy (Šotkovská \& Hugec, 1999; Turek \& Hugec, 1996). Tento rozdíl však není statisticky významný na úrovni $p<0,0500$. U některých ukazatelů skutečně dosáhli neromští chlapci lepších výsledků (běh, shyby, především předklon), u skoku z místa dosáhli lepšího výsledku naopak chlapci romského etnika. Žádná z těchto diferencí však nebyla statisticky významná. I přesto se jeví výsledky především ve flexibilitě (předklony) jako překvapující. Z empirie je u chlapců romského etnika (ale i dívek) patrný zájem o úpolové a taneční pohybové aktivity, které vyžadují a rozvíjejí koordinační schopnosti, včetně flexibility. Navzdory tomuto názoru naše výsledky potvrzují, že flexibilita je u neromských chlapců na vyšší úrovni.

Tabulka 6 Popisné statistiky všech dívek zkoumaného souboru

\begin{tabular}{|c|c|c|c|c|}
\hline $\begin{array}{c}\text { Test } \\
\text { N=74 }\end{array}$ & Průměr & Minimum & Maximum & Sm. odch. \\
\hline běh & 12.82 & 10.1 & 17.2 & 1.6599 \\
\hline výdrž ve shybu & 6.24 & 0 & 24 & 6.43233 \\
\hline předklon & 7.79 & 1 & 16 & 4.36618 \\
\hline skok & 141,29 & 97 & 208 & 25.4695 \\
\hline
\end{tabular}

Tabulka 7 Popisné statistiky dívek romského etnika

\begin{tabular}{|c|c|c|c|c|}
\hline $\begin{array}{c}\text { Test } \\
\text { N=28 }\end{array}$ & Průměr & Minimum & Maximum & Sm. odch. \\
\hline běh & 13.29 & 10.8 & 17.2 & 2.54783 \\
\hline výdrž ve shybu & 5.57 & 0 & 20 & 6.80336 \\
\hline předklon & 7.86 & 3 & 16 & 5.20988 \\
\hline skok & 134.71 & 97 & 182 & 28.1408 \\
\hline
\end{tabular}

Tabulka 8 Popisné statistiky dívek neromských

\begin{tabular}{|c|c|c|c|c|}
\hline $\begin{array}{c}\text { Test } \\
\mathrm{N}=46\end{array}$ & Průměr & Minimum & Maximum & Sm. odch. \\
\hline běh & 12.53 & 10.1 & 15.8 & 1.48918 \\
\hline výdrž ve shybu & 6.64 & 0 & 24 & 6.44148 \\
\hline předklon & 7.75 & 1 & 16 & 4.28695 \\
\hline skok & 145.30 & 98 & 208 & 25.0614 \\
\hline
\end{tabular}


Tabulka 9 Výsledné hodnoty zpracované podle Mann-Whitneyova testu

\begin{tabular}{|c|c|c|c|c|c|}
\hline \multicolumn{7}{|c|}{ Mann-Whitneyův U test } \\
\hline & $\mathrm{Z}$ & úroveň $\mathrm{p}$ & $\mathrm{Z}$ & úroveň $\mathrm{p}$ & \\
\hline & neupravené & neupravené & upravené & upravené & přesné $\mathrm{p}$ \\
\hline běh & $-0,52008$ & 0,603011 & $-0,52041$ & 0,602781 & 0,619851 \\
\hline výdrž ve shybu & 0,465332 & 0,641694 & 0,470719 & 0,637842 & 0,658294 \\
\hline předklon & 0,136862 & 0,89114 & 0,137307 & 0,890788 & 0,90412 \\
\hline skok & 1,094898 & 0,273562 & 1,095121 & 0,273465 & 0,286391 \\
\hline
\end{tabular}

U dívek romského etnika jsme potvrdili předešlé výzkumy v oblasti diferencí motorických schopností u žáků romského etnika a Neromů (Šotkovská \& Hugec, 1999; Turek \& Hugec, 1996) ve výdrži ve shybu (silových schopnostech), ve skoku z místa (odrazová síla dolních končetin) a předklonu (flexibilita). Neromské dívky dosáhly lepších výsledků ve výše uvedených testovaných oblastech než dívky romského etnika, avšak ne na hladině statistické významnosti. Naopak v běhu dosáhly lepších výsledků dívky romského etnika.

Vypočítané hodnoty testu jsou významné na hladině $\mathrm{p}, \mathrm{kdy} \mathrm{p}<0.05000$. V silových schopnostech, odrazové síle dolních končetin, rychlosti i flexibilitě však vždy výsledná hodnota nepřevyšovala hladinu p statisticky významným rozdílem. Podle výpočtů tedy není statisticky významný rozdíl mezi chlapci romského etnika a neromskými chlapci, ani mezi dívkami romského etnika a neromskými dívkami.

Výsledky, které seznamují s vývojem úrovně motorických schopností, uvádíme $\mathrm{v}$ grafech. $\mathrm{Z}$ důvodu přehlednosti jsme oddělili skok od běhu, shybu a předklonu.

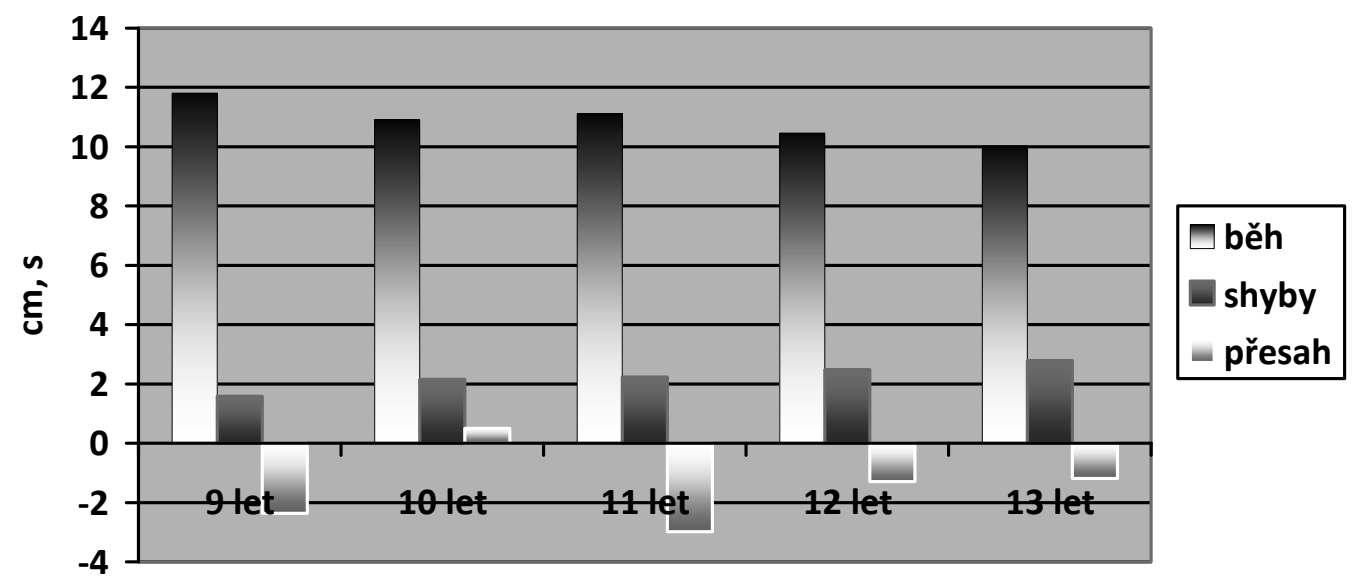

Obr. 1 Vývoj úrovně motorických schopností u chlapců romského etnika

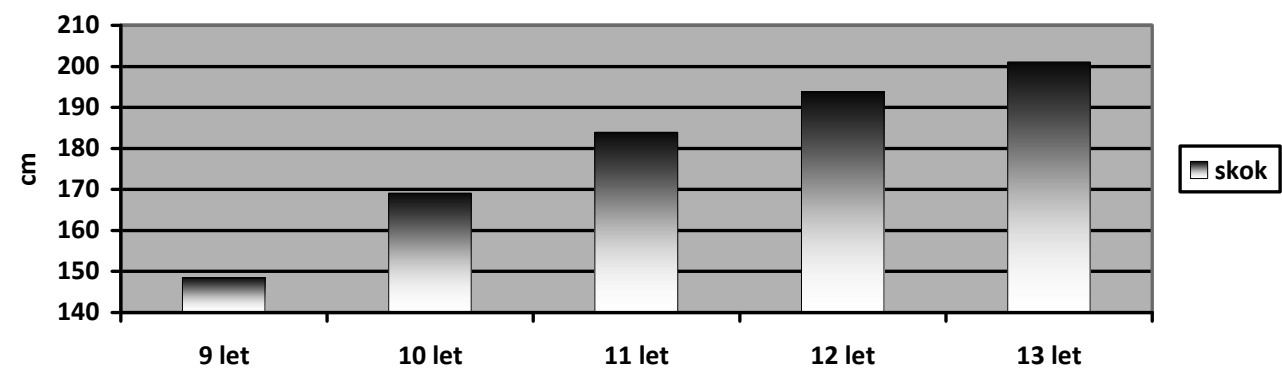

Obr. 2 Vývoj úrovně motorických schopností u chlapců romského etnika - skok 
U chlapců romského etnika jsme zjistili stabilní nárůst úrovně motorických schopností v počtu shybů (tedy silových schopnostech) a především skoků (tedy odrazová síla dolních končetin). Naprosto nestabilní se jeví výsledky předklonů (flexibilita). V běhu (rychlostní schopnosti) jsme, i př̀es drobné výkyvy výsledků u chlapců ve věku 11 let, zaznamenali postupné zvyšování úrovně schopností.

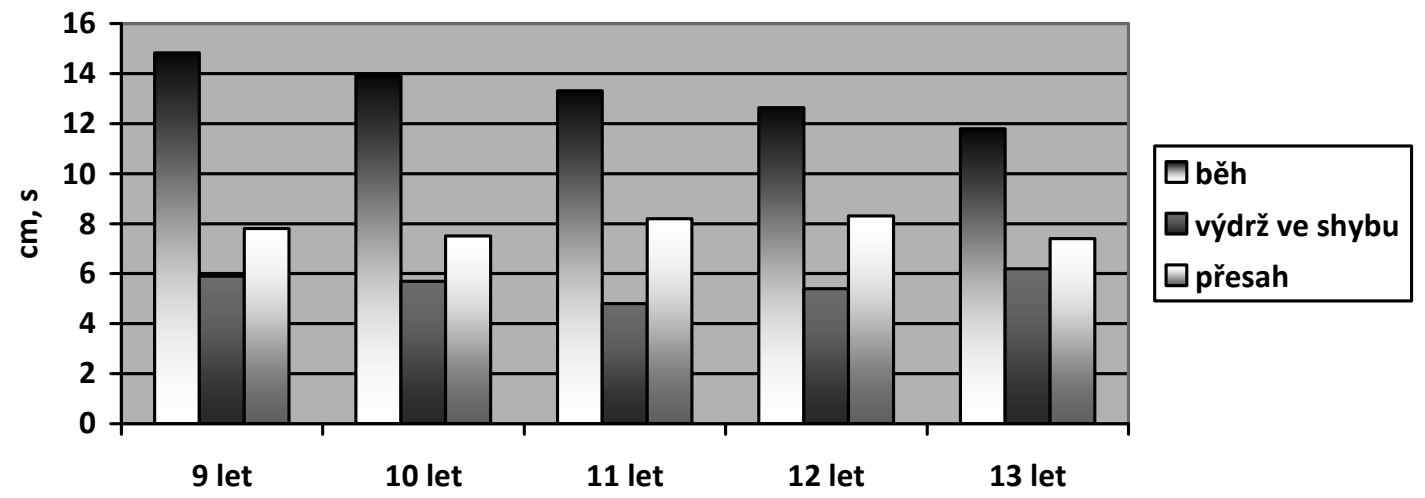

Obr. 3 Vývoj úrovně motorických schopností u dívek romského etnika

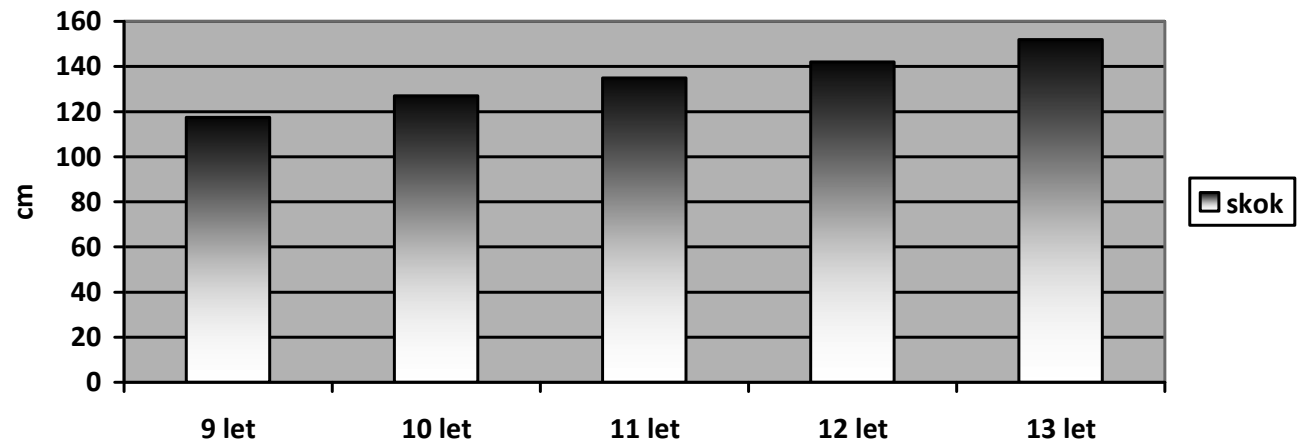

Obr. 4 Vývoj úrovně motorických schopností u dívek romského etnika - skok

U dívek romského etnika jsme zjistili stejně jako u chlapců stabilní zvyšování výkonnosti v průběhu věku ve skoku (odrazová síla dolních končetin), stejně tak jako v běhu (rychlostní schopnosti). Naopak $\mathrm{v}$ předklonu a výdrži ve shybu byla zjištěná úroveň v průběhu věku kolísavá. Vzhledem $\mathrm{k}$ malému počtu probandů však není možné výsledky generalizovat.

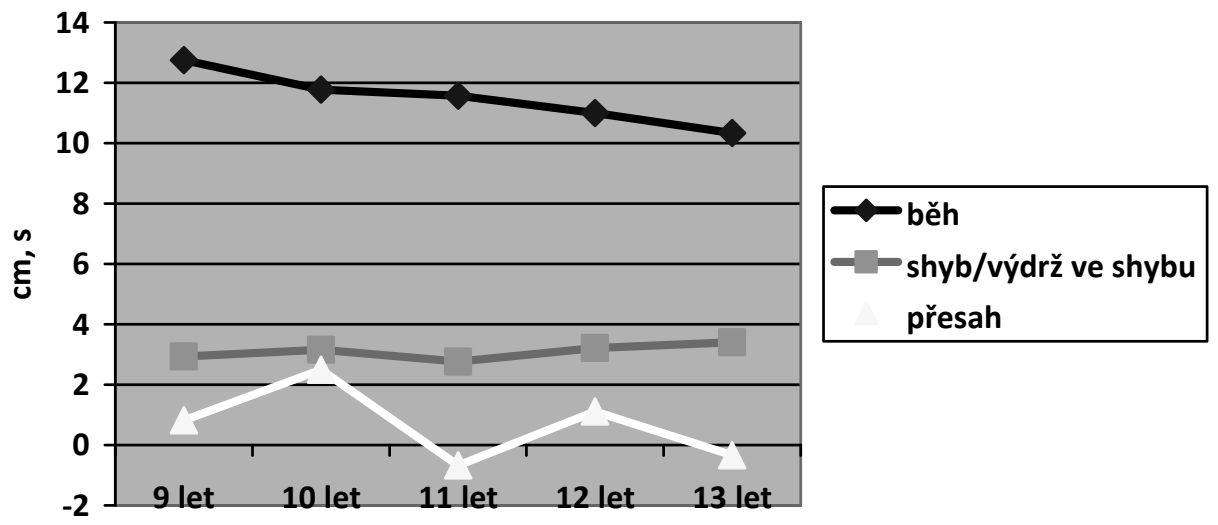

Obr. 5 Vývoj úrovně motorických schopností u žáků romského etnika - skok 


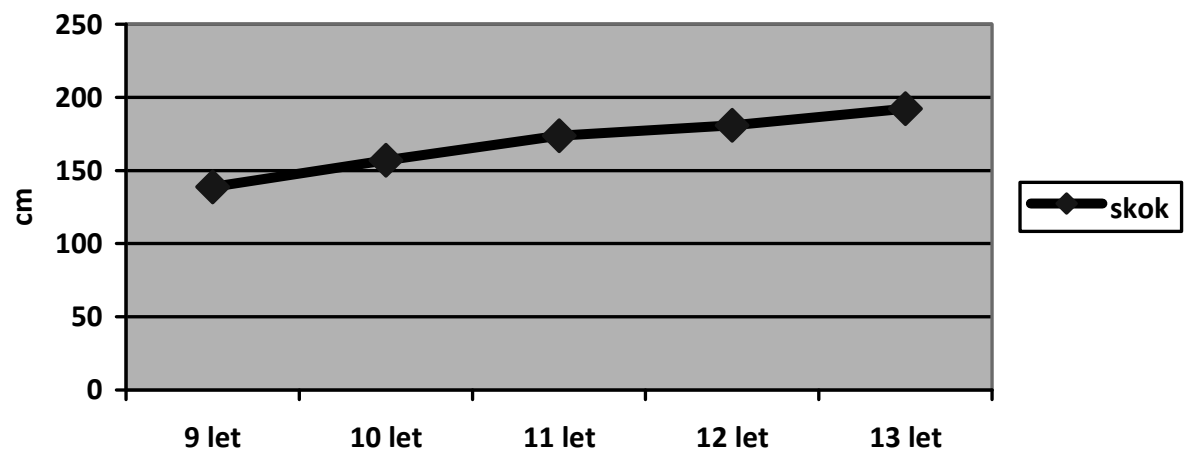

Obr. 6 Vývoj úrovně motorických schopností u žáků romského etnika - skok

Při pohledu na celkové výsledky je patrné, že úroveň rychlostních schopností a odrazové síly dolních končetin se v průběhu věku probandů zvyšuje. Silové schopnosti vykazují stabilitu, což je však způsobeno především výsledky samotného testu, který nezohledňuje hmotnost probanda. Výsledky testu zaměřeného na flexibilitu jsou se vzrůstajícím věkem probandů značně kolísavé.

\section{Závěr}

Jaká je úroveň motorických schopností chlapců a dívek romského etnika v komparaci s neromskými spolužáky?

Stejně jako u chlapců i u dívek jsme potvrdili některé předešlé výzkumy v oblasti diferencí motorických schopností u žáků romského etnika a Neromů (Šotkovská \& Hugec, 1999; Turek \& Hugec, 1996). U odrazové síly dolních končetin, $v$ silových schopnostech a flexibilitě dosáhly neromské dívky lepších výsledků než dívky romského etnika. Naopak v rychlostních schopnostech dosáhly lepších výsledků dívky romského etnika. U některých ukazatelů dosáhli neromští chlapci lepších výsledků (rychlostní a silové schopnosti, flexibilita), u odrazové síly dolních končetin dosáhli lepšího výsledku naopak chlapci romského etnika. Žádná $\mathrm{z}$ těchto schopností však nebyla statisticky významná na hladině $\mathrm{p}<0.05000$. Jelikož diference v úrovni motorických schopností nebyly statisticky významné, nepotvrzujeme rozdíl mezi chlapci romského etnika a neromskými chlapci, ani mezi dívkami romského etnika a neromskými dívkami v úrovni motorických schopností.

Jak se vyvíjí úroveň motorických schopností u žáků romského etnika v průběhu základního vzdělávání (9-13 let)?

Při pohledu na celkové výsledky je patrné, že úroveň rychlostních schopností a odrazové síly dolních končetin se v průběhu věku probandů zvyšuje. Silové schopnosti vykazují stabilitu, což je způsobeno především výsledky samotného testu, který nezohledňuje hmotnost probanda. Výsledky testu zaměřeného na flexibilitu jsou se vzrůstajícím věkem probandů značně nestabilní.

\section{Referenční seznam}

Baranowski, T., Bouchard, C., Bar-Or, O. et al. (1994). Assessment, prevalence, and cardiovascular benefits of physical activity and fitness in youth. Medicine \& Science in Sports \& Exercise, 24(6), 237-47.

Belásová, L. (2001). Analýza úrovne čitatel’ských a grafomotorických spôsobilostí rómskych žiakov 1. ročnika ZŠ. In Rómské etnikum v systéme multikultúrnej edukácie: zborník z medzinárodnej vedeckej konferencie (pp. 182-187). Prešov: PF PU.

Block, M. (2007). A teacher's guide to including student with disabilities in general physical education (3rd ed.). Maryland: Paul H. Brooks Publishing Co.

Boyce, B. A. (1996). Dealing with student diversita through the case study approach. Journal of Physical Education, Recreation and Dance, 67(5), 46-50. 
Butt, K. L., \& Pahnos, M. L. (1995). Why we need a multicultural focus in our schools. Journal of Physical Education, Recreation and Dance, 66(1), 48-53.

Freedson, P. S. (1991). Electronic motion sensors and heart rate as measures of physical activity in children. Journal of School Health, 61(5), 220-223.

Harrison, L., \& Worthy, T. (2001). „Just like all the rest“: Developing awareness of stereotypical thinking in physical education. Journal of Physical Education, Recreation and Dance, 72(9), 20-24.

Hendl, J. (2004). Přehled statistických metod. Praha: Portál.

Hodge, S. R. (1997). Mentoring: Perspectives of physical education graduate students from diverse cultural backgrounds. Physical Educator, 54(4), 181-195.

Hutchinson, G. E. (1995). Gender fait teaching in physical education. Journal of Physical Education, Recreationa and Dance, 66(1), 42-47.

Chepyator-Thomson, J. (1994). Multicultural education. Culturally responsive teaching. Journal of Physical Education, Recreation and Dance, 65(9), 31-32.

Kahan, D. (2003). Islam and physical activity: Implications for American sport and physical educators. Journal of Physical Education, Recreation and Dance, 74(3), 48-54.

King, S. E. (1994). Winning the race against racism. Journal of Physical Education, Recreation and Dance, 65(9), 69-74.

Liba, J. (1999). Pohybová výchova rómskych žiakov. In Perspektívy edukácie žiakov z výchovne menej podnetného prostredia: zborník $z$ medzinárodnej vedeckej konferencie v Prešove (pp 81-85). Prešov: Pedagogická fakulta Prešovšká Univerzita.

McCollum, S., Civalier, A., \& Holt, A. (2004). Equitable learning for Spanish speaking students in elementary physical education. Strategies, 17(6), 21-23.

Měkota, K., Kováŕ, R. (1996). Manuál pro hodnocení motorické výkonnosti a vybraných charakteristik tělesné stavby mládeže a dospělých v České republice. Praha: Univerzita Karlova, FTVS.

Pate, R. R., Trost, S. G., Felton, G. M. et al. (1997). Correlates of physical activity behaviour in rural youth. Res. Questionnaire Exercise Sport, 68(3), 241-248.

Sallis, J. F., \& Patrick K. (1994). Physical activity guidelines for adolescents: Consensus statement. Pediatric Exercise Science, 6, 302-314.

Sallis, J. F., Patterson, T. L., Buono, M. J. et al. (1988). Aggregation of physical activity habits in MexicanAmerican and Anglo families. Journal Behavioral Medicine, 11(1), 31-41.

Sallis, J. F., Prochaska, J. J., \& Taylor, W. C. (2000). A review of correlates of physical activity of children and adolescents. Medicine \& Science in Sports \& Exercise, 32(5), 963-975.

Sparks, W. G. III. (1994). Culturally responsive pedagogy: A framework for addressing multicultural issues. Journal of Physical Education, Recreation and Dance, 65(9), 33-36, 61.

Sutherland, S. L., \& Hodge, S. R. (2001). Inclusion of a diverse population. Teaching Elementary Physical Education, 12(2), 18-21.

Sutliff, M. (1996). Multicultural education for native American students in physical education. The Physical Educator, 53, 157-163.

Sutliff, M., \& Perry, J. (2000). Multiculturalism: Developing connections in elementary physical education. Strategies, 13(5), 33-36.

Šotkovská, V., \& Hugec, J. (1999). Vplyv telesnej výchovy na pohybovú výkonnost̉ 9-10 ročných žiakov z málopodnetného prostredia. In Perspektívy edukácie žiakov z výchovne menej podnetného prostredia: zborník z medzinárodnej vedeckej konferencie v Prešove. Prešov: Pedagogická Fakulta Prešovské Univerzity.

Trochtová, I. (2002). Rozvojový jazykový program pre rómske deti (zo sociálne znevýhodneneho prostredia). Prešov: Rokus

Trost, S. G., Pate, R. R., Saunders, R. et al. (1997). A prospective study of the determinants of physical activity in rural fifth grade children. Preventive Medicine, 26, 257-263. 
Turek, M., \& Hugec, J. (1996). Pohybová výkonnost̉ rómskych detí na I. stupni ZŠ. In Výchova a vzdelávanie detí zo sociálne znevýhodneného prostredia: zborník prispevkov z medzinárodnej vedeckej konferencie. Prešov: Pedagogická Fakulta UPJŠ v Košiciach.

Wessinger, N. P. (1994). Celebrating our differences: Fostering ethnicity in homogenous settings. Journal of Physical Education, Recreation and Dance, 65(9), 62-68. 